\title{
STUDI OPTIMASI PEMANFAATAN WADUK WAY APU DI PROVINSI MALUKU UNTUK JARINGAN IRIGASI, KEBUTUHAN
} AIR BAKU, DAN POTENSI PLTA

\author{
Radita Ahadunnisa, Nadjadji Anwar dan Nastasia Festy Margini.
}

Jurusan Teknik Sipil, Fakultas Teknik Sipil dan Perencanaan, Institut Teknologi Sepuluh Nopember (ITS)

\author{
Jl. Arief Rahman Hakim, Surabaya 60111 \\ E-mail: ditadunnisa@gmail.com
}

\begin{abstract}
Abstrak - Waduk Way Apu terletak di aliran Sungai Way Apu dan masuk wilayah Kecamatan Waeapo di Pulau Buru, Provinsi Maluku. Secara geografis sesuai dengan koordinat UTM, Waduk Way Apu terletak di koordinat X = 260630,764 dan $Y=9608598$. Waduk Way Apu mampu mengairi 5726 ha sawah padi. Waduk Way Apu direncanakan mampu untuk memenuhi kebutuhan irigasi, air baku, dan potensi PLTA.

Sehubungan dengan permasalahan tersebut diatas, perlu adanya studi optimasi Waduk Way Apu untuk pemanfaatan irigasi, kebutuhan air baku, dan potensi PLTA. Dengan adanya studi optimasi dapat diketahui pengaturan cara pemberian air yang baik dan pengaturan pola tanam. Hal tersebut ditindaklanjuti dengan studi optimasi antara pola tanam dan kebutuhan air baku serta potensi PLTA sehingga fungsi dari Waduk Way Apu dapat digunakan secara optimal. Untuk analisa ini digunakan program linier dengan program bantu POM-QM for Windows 3.

Dari hasil analisa yang telah dilakukan, didapatkan beberapa kesimpulan yaitu Debit andalan yang digunakan untuk menghitung besar kebutuhan air adalah Debit Andalan 80\% terbesar adalah $21.27 \mathrm{~m}^{3} / \mathrm{detik}$ dan Debit Andalan 80\% terkecil adalah $0.95 \mathrm{~m}^{3} /$ detik, Alternatif Pola Tanam yang paling optimal adalah Alternatif Pola Tanam 1 dengan masa awal tanam Nopember 1, besar kebutuhan air untuk kebutuhan air baku pada tahun 2012 pada kondisi jam puncak adalah sebesar 44.67 liter/detik, dan besar energi yang dihasilkan dari perhitungan potensi PLTA didapatkan daya sebesar $152.16 \mathrm{~kW}$ dengan Debit Andalan 90\% sebesar $2.47 \mathrm{~m}^{3} /$ detik.
\end{abstract}

Kata kunci: Waduk Way Apu, Optimasi, Irigasi, PLTA, Air Baku, Program Linier.

\section{PENDAHULUAN}

Waduk Way Apu terletak di aliran Sungai Way Apu dan masuk wilayah Kecamatan Waeapo di Pulau Buru, Provinsi Maluku, seperti yang ditunjukkan pada Gambar 1. Secara geografis sesuai dengan koordinat UTM, Waduk Way Apu terletak di koordinat $\mathrm{X}=260630,764$ dan $\mathrm{Y}=$ 9608598. Waduk Way Apu mampu mengairi 5726 ha sawah padi. Waduk Way Apu direncanakan mampu untuk memenuhi kebutuhan irigasi, air baku, dan potensi PLTA.

Sektor pertanian memegang peranan penting dalam memberikan kontribusi bagi pendapatan di Kecamatan Waepo. 92 dari 111 unit usaha yang ada di Kecamatan Waeapo adalah Unit Usaha Industri Hasil Pertanian, sehingga produktivitasnya perlu terus ditingkatkan. Ketersediaan air pada musim hujan mengalami peningkatan karena debit air yang melimpah namun ketersediaan air pada musim kemarau mengalami penurunan. Hal tersebut mengakibatkan Sungai Way Apu masih belum bisa memasok kebutuhan air irigasi untuk lahan pertanian secara optimal.
Jumlah penduduk Kecamatan Waepo pada tahun 2010 adalah 34.153 jiwa dan pada tahun 2012 meningkat menjadi 37095 jiwa. Seiring dengan bertambahnya penduduk di Kecamatan Waeapo mengakibatkan kebutuhan air baku dan kebutuhan akan listrik semakin meningkat. Ada 11 desa dari 32 desa yang ada di Kecamatan Waeapo yang masih belum memiliki fasilitas listrik.

Sehubungan dengan permasalahan tersebut diatas, perlu adanya studi optimasi Waduk Way Apu untuk pemanfaatan irigasi, kebutuhan air baku, dan potensi PLTA. Dengan adanya studi optimasi dapat diketahui pengaturan cara pemberian air yang baik dan pengaturan pola tanam. Hal tersebut ditindaklanjuti dengan studi optimasi antara pola tanam dan kebutuhan air baku serta potensi PLTA sehingga fungsi dari Waduk Way Apu dapat digunakan secara optimal. Untuk analisa ini digunakan program linier dengan program bantu POM-QM for Windows 3. 


\section{Permasalahan utama:}

Berapa besar debit inflow andalan dari Waduk Way Apu sehingga dapat dimanfaatkan untuk kebutuhan irigasi, kebutuhan air baku, dan potensi PLTA?

Detail permasalahan:

1. Berapa besar kebutuhan air untuk kebutuhan irigasi dari tiap - tiap alternatif pola tanam?

2. Berapa besar kebutuhan air untuk kebutuhan air baku?

3. Berapa besar potensi PLTA yang dapat dihasilkan?

\section{METODOLOGI}

\section{Diagram Alir}

Diagram Alir Pengerjaan Tugas Akhir

Berikut ini merupakan diagram alir dalam pengerjaan Tugas Akhir ini:



Gambar 1. Diagram Alir Pengerjaan Tugas Akhir

\section{Diagram Alir Optimasi Linier Programming}

Berikut ini merupakan diagram alir optimasi linier programming untuk mendapatkan alternatif pola tanam yang paling optimal:

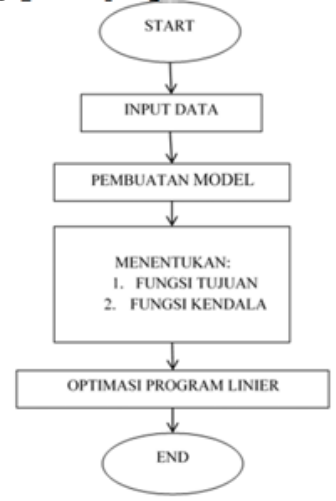

Gambar 2. Diagram Alir Optimasi Linier Programming

Keterangan:
Fungsi tujuan $=$ untuk memaksimalkan luas areal tanam yang dapat ditanami oleh tanaman pada setiap musimnya.

Fungsi kendala $=$ batasan atau kendala seperti debit air dan luas areal tanam yang tersedia.

\section{Skema Keseimbangan Air Waduk}

Berikut ini merupakan skema keseimbangan air waduk dalam pengerjaan tugas akhir ini:

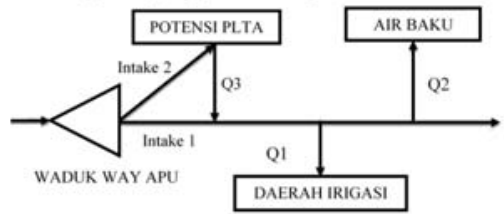

\section{Gambar 3. Skema Keseimbangan Air Waduk}

\section{HASIL DAN PEMBAHASAN}

1. Analisa Debit Andalan

Perhitungan Evapotranspirasi Potensial

Perhitungan Evapotranspirasi menggunakan metode Penman Modifikasi yang melibatkan temperatur udara, kelembaban relatif, lama penyinaran matahari, dan kecepatan angin. Berikut ini merupakan Perhitungan Evapotranspirasi Potensial Tahun 2012:

Tabel 1. Perhitungan Evapotranspirasi Potensil Tahun 2012.

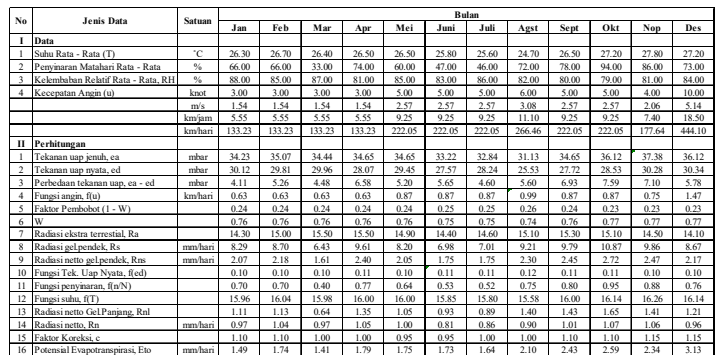

(Sumber: Hasil Perhitungan)

Berikut ini merupakan rekap perhitungan evapotranspirasi potensial tahun 2003 - 2012:

Tabel 2. Rekap Perhitungan Evapotranspirasi Potensil Tahun 2003-2012.

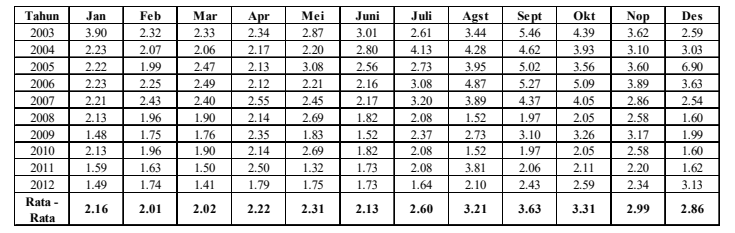

(Sumber: Hasil Perhitungan)

\section{Perhitungan Debit Aliran Rendah}

Perhitungan debit aliran rendah menggunakan metode F.J. Mock dengan pendekatan 
Studi Optimasi Pemanfaatan Waduk Way Apu di Provinsi Maluku untuk Jaringan Irigasi, Kebutuhan Air Baku, dan Potensi PLTA

perhitungan aliran permukaan yang terjadi di sungai. Berikut ini merupakan perhitungan debit aliran rendah pada tahun 2012:

Tabel 3. Perhitungan Debit Aliran Rendah Tahun 2012.

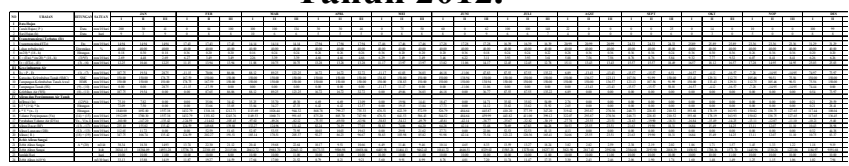

(Sumber: Hasil Perhitungan)

Tabel 4. Rekap Perhitungan Debit Aliran Rendah Tahun 2003 - 2012.

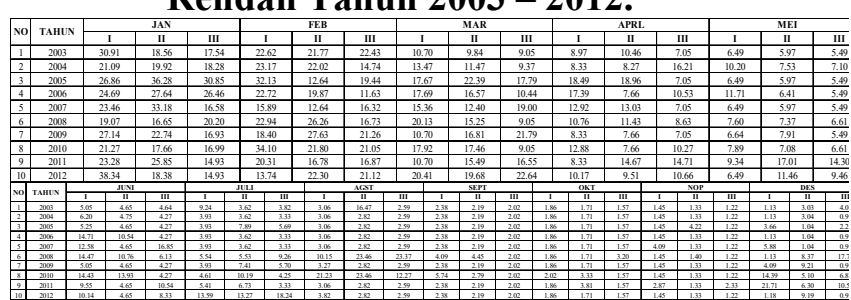

(Sumber: Hasil Perhitungan)

\section{Perhitungan Debit Andalan}

Debit Andalan yang ditetapkan adalah Debit Andalan $80 \%$ yang berarti akan dihadapi resiko adanya debit - debit yang lebih kecil dari debit andalan sebesar $20 \%$ pengamatan. Berikut ini merupakan rekap debit andalan:

\section{Tabel 5. Rekap Perhitungan Debit Andalan}



(Sumber: Hasil Perhitungan)

\section{Analisa Kebutuhan Air untuk Irigasi}

\section{Perhitungan Curah Hujan Efektif}

Curah hujan efektif merupakan curah hujan yang jatuh pada suatu daerah dan dapat digunakan tanaman untuk pertumbuhannya untuk memenuhi kehilangan air akibat evapotranspirasi tanaman, perkolasi dan lain - lain. Berikut ini merupakan perhitungan curah hujan efektif untuk tanaman padi dan polowijo:
Tabel 6. Perhitungan Curah Hujan Efektif untuk Tanaman Padi ( $\mathrm{mm} / \mathrm{hari}$ )

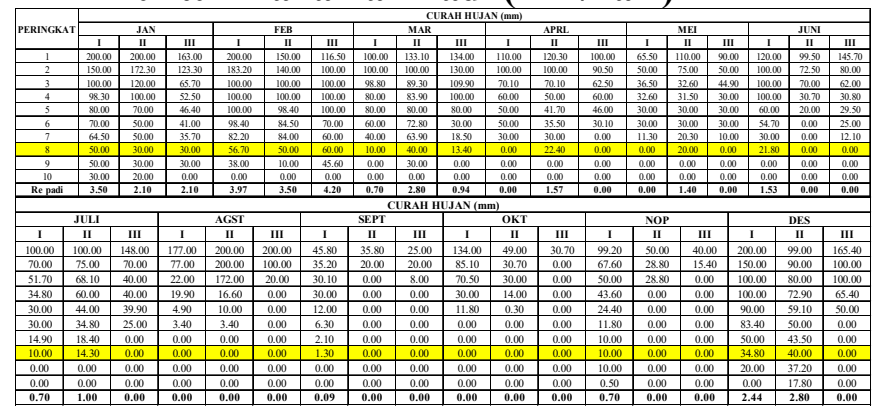

(Sumber: Hasil Perhitungan)

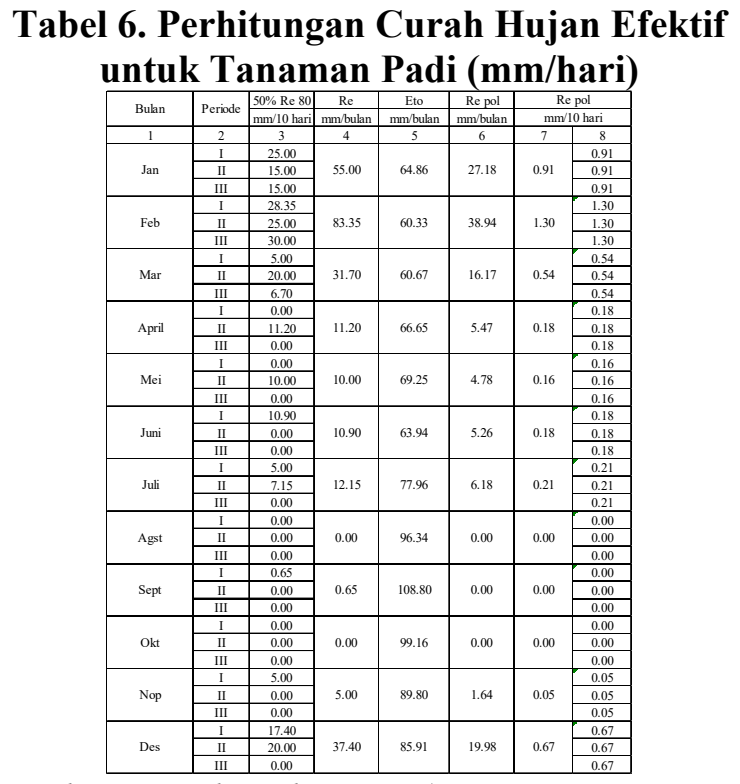

(Sumber: Hasil Perhitungan)

\section{Perhitungan Kebutuhan Air untuk Penyiapan Lahan}

Perhitungan kebutuhan air untuk penyiapan lahan menggunakan metode Van de Goor \& Zijlstra (1968) yang dipengaruhi oleh evapotranspirasi potensial dan perkolasi. Berikut ini merupakan perhitungan kebutuhan air untuk penyiapan lahan:

Tabel 7. Perhitungan Kebutuhan Air untuk Penyiapan Lahan.

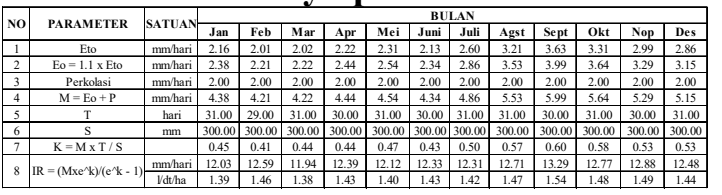

(Sumber: Hasil Perhitungan)

3. Perhitungan Alternatif Pola Tanam

Musim tanam pada studi optimasi ini adalah sebagai berikut:

Musim Tanam Hujan : November - Februari 
Musim Tanam Kemarau 1 : Maret - Juni Musim Tanam Kemarau II : Juli-Oktober Alternatif pola tanam pada studi optimasi ini adalah sebagai berikut:

1. Alternatif 1 : Awal masa tanam pada bulan November I

2. Alternatif 2 : Awal masa tanam pada bulan November II

3. Alternatif 3 : Awal masa tanam pada bulan November III

4. Alternatif 4 : Awal masa tanam pada bulan Desember I

5. Alternatif 5 : Awal masa tanam pada bulan Desember II

6. Alternatif 6 : Awal masa tanam pada bulan Desember III

Berikut ini merupakan perhitungan Alternatif Pola Tanam 1 dengan masa tanam November 1:

Tabel 8. Perhitungan Alternatif Pola Tanam 1

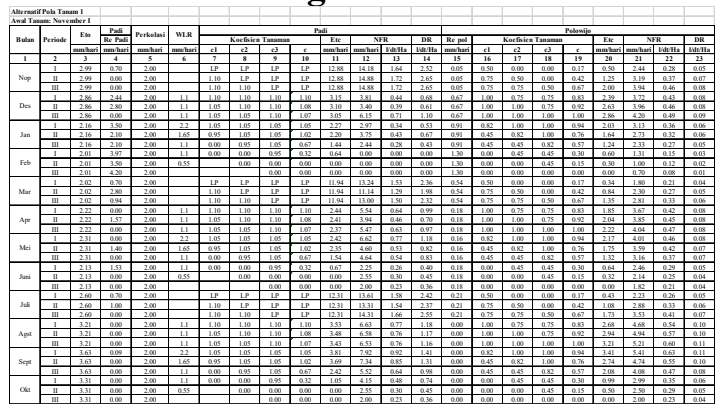

(Sumber: Hasil Perhitungan)

4. Analisa Kebutuhan Air untuk Air Baku

Proyeksi Jumlah Penduduk

Perhitungan proyeksi jumlah penduduk Kecamatan Waeapo menggunakan metode aritmatik dan geomatrik. Berikut ini merupakan perhitungan proyeksi penduduk Kecamatan Waeapo dari tahun 2012 hingga tahun 2100:

Tabel 9. Perhitungan Proyeksi Penduduk Kecamatan Waeapo.

\begin{tabular}{|c|c|c|}
\hline \multirow{2}{*}{ Tahun } & \multirow{2}{*}{$\mathbf{n}$} & Metode Geometrik \\
\cline { 3 - 3 } & & $\mathbf{P n = 3 7 0 9 3 * ( 1 + 0 . 0 2 8 8})^{\wedge} \mathbf{n}$ \\
\cline { 3 - 3 } & & Jiwa \\
\hline $\mathbf{1}$ & $\mathbf{2}$ & $\mathbf{3}$ \\
\hline 2012 & 0 & 37093.00 \\
\hline 2013 & 1 & 38161.28 \\
\hline 2014 & 2 & 39260.32 \\
\hline 2015 & 3 & 40391.02 \\
\hline 2016 & 4 & 41554.28 \\
\hline 2017 & 5 & 42751.05 \\
\hline 2018 & 6 & 43982.28 \\
\hline 2019 & 7 & 45248.96 \\
\hline 2020 & 8 & 46552.14 \\
\hline 2021 & 9 & 47892.84 \\
\hline 2022 & 10 & 49272.15 \\
\hline &
\end{tabular}

Hal 54
(Sumber: Hasil Perhitungan)

5. Perhitungan Kebutuhan Air Baku

Perhitungan kebutuhan air baku meliputi sektor Domestik (Sambungan Rumah Tangga dan Hidran Umum) dan sektor Non-Domestik (Fasilitas pendidikan, pasar, perkantoran, dan puskesmas). Berikut ini adalah jumlah kebutuhan air baku Kecamatan Waeapo untuk tahun 2012 2100:

Tabel 10. Jumlah Kebutuhan Air Baku Kecamatan Waeapo untuk Tahun 2012 - 2100 \begin{tabular}{|c|c|c|c|c|c|c|c|}
\hline \multirow{2}{*}{ Tahun } & SR & HU & Pendidikan & Pasar & Perkantoran & Puskesmas & Jumlah \\
\cline { 2 - 8 } & It/detik & It/detik & It/detik & It/detik & lt/detik & It/detik & It/detik \\
\hline $\mathbf{1}$ & $\mathbf{2}$ & $\mathbf{3}$ & $\mathbf{4}$ & $\mathbf{5}$ & $\mathbf{6}$ & $\mathbf{7}$ & $\mathbf{8}$ \\
\hline 2012 & 21.04 & 3.86 & 0.41 & 0.15 & 0.05 & 0.02 & 25.53 \\
\hline 2013 & 21.64 & 3.98 & 0.42 & 0.16 & 0.04 & 0.02 & 26.26 \\
\hline 2014 & 22.27 & 4.09 & 0.43 & 0.16 & 0.05 & 0.02 & 27.02 \\
\hline 2015 & 22.91 & 4.21 & 0.44 & 0.17 & 0.05 & 0.02 & 27.79 \\
\hline 2016 & 23.57 & 4.33 & 0.46 & 0.17 & 0.05 & 0.02 & 28.59 \\
\hline 2017 & 24.25 & 4.45 & 0.47 & 0.18 & 0.05 & 0.02 & 29.42 \\
\hline 2018 & 24.94 & 4.58 & 0.48 & 0.18 & 0.05 & 0.02 & 30.26 \\
\hline 2019 & 25.66 & 4.71 & 0.50 & 0.19 & 0.05 & 0.02 & 31.13 \\
\hline 2020 & 26.40 & 4.85 & 0.51 & 0.19 & 0.05 & 0.02 & 32.03 \\
\hline 2021 & 27.16 & 4.99 & 0.53 & 0.20 & 0.05 & 0.02 & 32.95 \\
\hline 2022 & 27.94 & 5.13 & 0.54 & 0.21 & 0.06 & 0.02 & 33.90 \\
\hline
\end{tabular}

(Sumber: Hasil Perhitungan)

6. Analisa Kebutuhan Air untuk Potensi PLTA

\section{Lengkung Durasi}

Lengkung Durasi atau Duration Curve digunakan untuk menentukan Debit Air Q90, Q80, Q75, dan Q 50 yang kemudikan dipakai sebagai $Q$ turbin. Berikut ini adalah Lengkung Durasi:

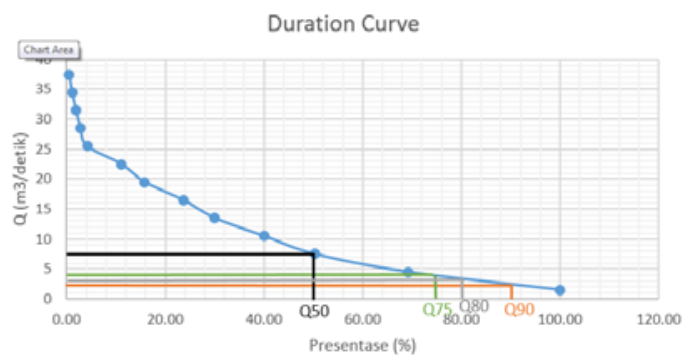

Gambar 4. Grafik Lengkung Durasi

(Sumber: Hasil Perhitungan)

Berdasarkan Grafik Lengkung Durasi diatas, didapatkan:

Debit Air $\mathrm{Q}_{90}=2.47 \mathrm{~m}^{3} /$ detik

Debit Air $\mathrm{Q}_{80}=3.45 \mathrm{~m}^{3} /$ detik

Debit Air $\mathrm{Q}_{75}=3.93 \mathrm{~m}^{3} /$ detik

Debit Air $\mathrm{Q}_{50}=7.58 \mathrm{~m}^{3} / \mathrm{detik}$

Tingi Jatuh Efektif, $\mathrm{H}_{\text {eff }}$

Tinggi jatuh efektif didapatkan dari selisih antara elevasi dari permukaan air di upstream dan di downstream.

Elevasi upstream $=+58.98$

Elevasi downstream $=+50.00$ 
Studi Optimasi Pemanfaatan Waduk Way Apu di Provinsi Maluku untuk Jaringan Irigasi, Kebutuhan Air Baku, dan Potensi PLTA

$\mathrm{H}_{\text {eff }}$ bruto $=$ Elevasi upstream - Elevasi downstream

$\mathrm{H}_{\text {eff bruto }}=+58.98-(+50.00)=8.98 \mathrm{~m}$

$\mathrm{H}_{\text {eff losses }}=10 \% \times \mathrm{H}_{\text {eff bruto }}=0.10 \times 8.98$

$$
=0.898 \mathrm{~m}
$$

$\mathrm{H}_{\text {eff }}=\mathrm{H}_{\text {eff bruto }}-\mathrm{H}_{\text {eff losses }}$

$$
=8.98-0.898=8.082 \mathrm{~m}
$$

Tekanan maksimal 10\% dari Head bruto (Patty, 1995).

\section{Pemilihan Jenis Turbin}

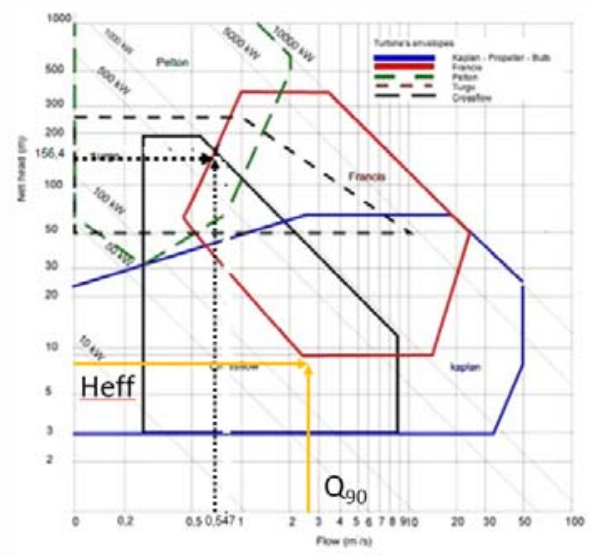

\section{Gambar 5.2. Pemilihan jenis turbin}

Berdasarkan Grafik pada Gambar 5.2. Turbin yang dipilih dengan Tinggi jatuh efektif 8.98 $\mathrm{m}$ dan besar debit air $2.47 \mathrm{~m}^{3} /$ detik adalah Turbin Kaplan.

Spesifikasi dari Turbin Kaplan:

Efisiensi turbin, $\eta=70 \%=0.70$

\section{Daya Listrik}

$\mathrm{P}=\eta \times \rho \times \mathrm{g} \times \mathrm{H}_{\mathrm{eff}} \times \mathrm{Q}$

$P_{90}=0.70 \times 1 \times 9.8 \times 2.47 \times 8.082=136.94 \mathrm{~kW}$

$\mathrm{P}_{80}=0.70 \times 1 \times 9.8 \times 3.45 \times 8.082=191.28 \mathrm{~kW}$

$\mathrm{P}_{75}=0.70 \times 1 \times 9.8 \times 3.93 \times 8.082=217.89 \mathrm{~kW}$

$\mathrm{P}_{50}=0.70 \times 1 \times 9.8 \times 7.58 \times 8.082=420.25 \mathrm{~kW}$

\section{Energi Listrik}

$$
\mathrm{E}=\mathrm{P} \times \mathrm{t}
$$

$E_{90}=136.94 \mathrm{~kW} \times 365$ hari $\times 24$ jam $=$ $1199594.4 \mathrm{kWh}$

$\mathrm{E}_{80}=191.28 \mathrm{~kW} \times 365$ hari $\times 24$ jam $=$ $1675612.8 \mathrm{kWh}$

$\mathrm{E}_{75}=217.89 \mathrm{~kW} \times 365$ hari $\times 24$ jam $=$ $1908716.4 \mathrm{kWh}$

$\mathrm{E}_{50}=420.25 \mathrm{~kW} \times 365$ hari $\times 24 \mathrm{jam}=3681390$ $\mathrm{kWh}$
7. Optimasi Kebutuhan Air Irigasi dengan Linier Programming

Permodelan Optimasi digunakan untuk menyelesaikan permasalahan dalam pemanfaatan air yang ada dengan tujuan untuk mengetahui seberapa besar hasil pengoptimasian dengan eksisting. Pada optimasi ini memiliki nilai suatu fungsi agar beberapa variable yang ada menjadi maksimum dengan memperhatikan kendala - kendala yang ada. Dalam studi optimasi ini menggunakan persamaan linier dengan mengggunakan program aplikasi POMQM for Windows 3. Berikut ini adalah Model optimasi dan hasil optimasi dari Alternatif Pola Tanam 1:



Gambar 5. Model Optimasi Alternatif Pola Tanam 1

(Sumber: Input POM-QM for Windows 3)

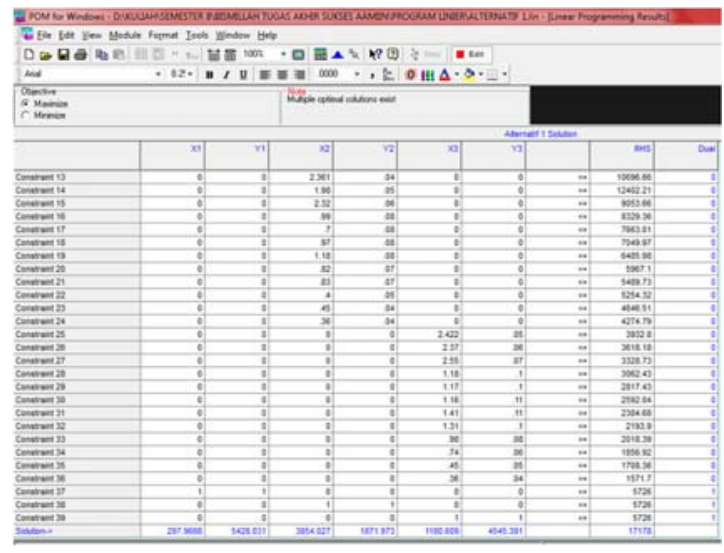

Gambar 6. Hasil Optimasi Alternatif Pola Tanam 1

(Sumber: Output POM-QM for Windows 3) 
Dari hasil optimasi tersebut didapatkan Luas lahan dan dapat diketahui intensitas tanam, yakni:

Tabel 11. Luas Lahan, Intensitas Tanam, dan Keuntungan Produksi.

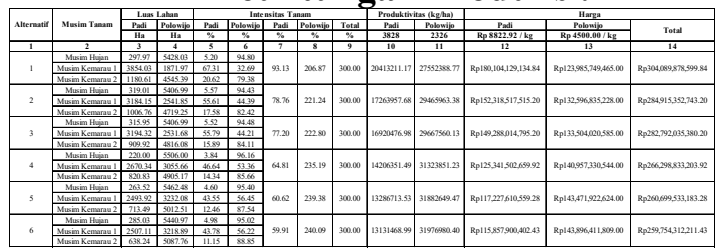

(Sumber: Output POM-QM for Windows 3 dan Hasil Perhitungan)

Dikarenakan tanaman padi tidak bisa ditanam terus - menerus sepanjang tahun pada lahan yang sama, maka lahan yang digunakan berbeda di tiap musim tanamnya. Untuk mengetahui alternative mana yang akan digunakan, maka dipilih Alternatif yang memiliki keuntungan hasil pertanian yang terbesar. Oleh sebab itu, Alternatif yang dipilih adalah Alternatif 1.

Berikut ini merupakan perhitungan total debit air yang dibutuhkan untuk irigasi untuk Alternatif Pola Tanam 1:

Tabel 12. Total Kebutuhan Air Irigasi untuk Alternatif Pola Tanam 1.

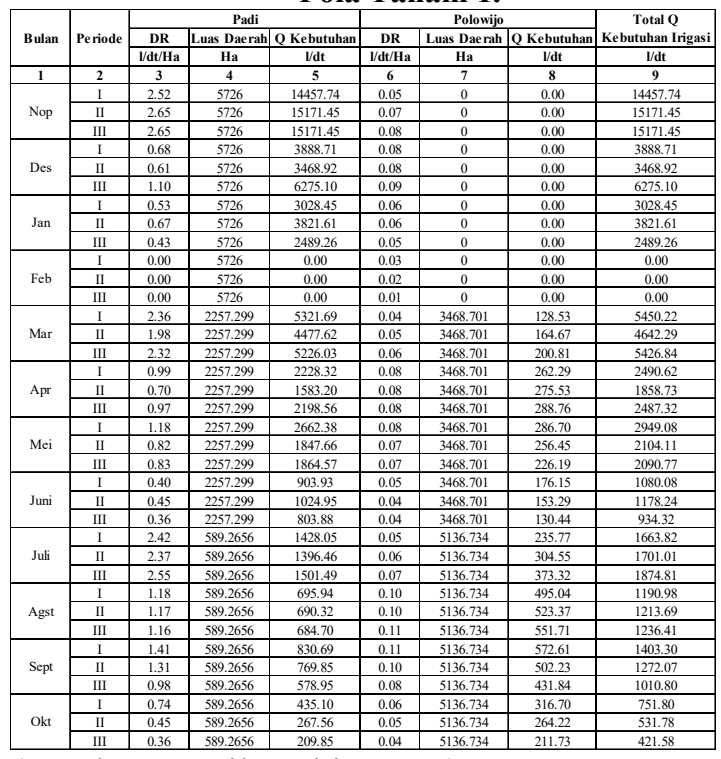

(Sumber: Hasil Perhitungan)

Berikut ini adalah rekap perhitungan total kebutuhan air untuk irigasi:

Tabel 13. Rekap Total Kebutuhan Air Irigasi.
(Sumber: Hasil Perhitungan)

\section{Analisa Water Balance Air Waduk}

Pada analisa water balance air waduk ini memperhitungkan jumlah air yang masuk ke suatu sistem dikurangi dengan jumlah air yang keluar dari suatu sistem tersebut dan tampungan waduk yang tersimpan tidak boleh habis. Berikut ini merupakan perhitungan Water Balance air Waduk Way Apu:

Tabel 14. Perhitungan Water Balance Air Waduk Way Apu.

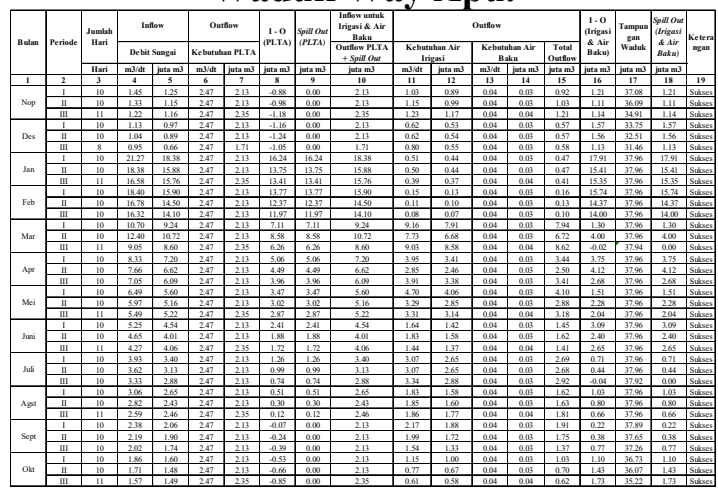

(Sumber: Hasil Perhitungan)

\section{KESIMPULAN DAN SARAN}

\section{Kesimpulan}

Dari hasil perhitungan dan analisa pada bab bab sebelumnya, dapat diambil beberapa kesimpulan sebagai berikut:

1. Dari perhitungan debit aliran rendah dengan menggunakan metode F.J.Mock didapatkan Debit Andalan 80\% terbesar adalah $21.27 \mathrm{~m}^{3} /$ detik dan Debit Andalan $80 \%$ terkecil adalah $0.95 \mathrm{~m}^{3} /$ detik untuk memenuhi kebutuhan irigasi, kebutuhan air baku, dan potensi PLTA.

2. Besar kebutuhan air untuk kebutuhan irigasi berdasarakan alternatif pola tanam adalah sebagai berikut:

3. Alternatif Pola Tanam $1=83264.42$ liter/detik 
Studi Optimasi Pemanfaatan Waduk Way Apu di Provinsi Maluku untuk Jaringan Irigasi, Kebutuhan Air Baku, dan Potensi PLTA

4. Alternatif Pola Tanam $2=73037.46$ liter/detik

5. Alternatif Pola Tanam $3=71742.59$ liter/detik

6. Alternatif Pola Tanam $4=62449.39$ liter/detik

7. Alternatif Pola Tanam $5=58540.77$ liter/detik

8. Alternatif Pola Tanam $6=57456.30$ liter/detik

9. Alternatif Pola Tanam yang paling optimal untuk digunakan adalah Alternatif Pola Tanam 1 dikarenakan memiliki luas lahan tanaman padi yang terbesar.

10. Besar kebutuhan air untuk kebutuhan air baku pada tahun 2012 pada kondisi normal adalah sebesar 25.53 liter/detik. Sedangkan besar kebutuhan air baku pada kondisi Hari Maksimum adalah sebesar 29.39 liter/detik dan pada kondisi Jam Puncak adalah sebesar 44.67 liter/detik.

11. Besar Debit Andalan 90\% yang digunakan adalah sebesar $2.47 \mathrm{~m}^{3} /$ detik untuk perhitungan potensi PLTA dan dapat membangkitkan daya listrik hingga mencapai $152.16 \mathrm{~kW}$.

\section{Saran}

Adapun saran yang dapat diberikan berdasarkan hasil perhitungan dan analisa dalam pengerjaan Tugas Akhir ini adalah sebagai berikut:

1. Jika hasil optimasi ini akan diterapkan pada wilayah studi, maka perlu dilakukannya perhitungan Water Balance

untuk menghitung keseimbangan air yang masuk dan keluar Waduk.

2. Jika bangunan PLTA sudah ada, maka perlu dilakukan perhitungan kembali untuk Potensi PLTA.

3. Untuk pihak lain yang berminat mendalami subjek ini dapat mencoba cara optimasi yang lain.

\section{DAFTAR PUSTAKA}

[1] Angela, Nora. 2009. Studi Optimasi Pemanfaatan Air Waduk Ngebel di Kabupaten Ponorogo untuk Irigasi dan PLTA dengan Menggunakan Program Linier. Teknik Sipil ITS, Surabaya.

[2] Anwar, Nadjadji. 2001. Analisa Sistem Untuk Teknik Sipil. Teknik Sipil ITS, Surabaya.

[3] Anwar, Nadjadji. 2012. Rekayasa Sumber Daya Air. Teknik Sipil ITS, Surabaya.

[4] Effendy, Bambang. 2013. SID Bendungan Way Apu Pulau Buru Kabupaten Buru. Ambon : PT. ABCO Consultant.

[5] Handarwati Nur Rochmah, Reski. 2009. Studi Water Balance Waduk Kedung Brubus dan Waduk Notopuro untuk Pemanfaatan Air Baku dan Irigasi. Teknik Sipil ITS, Surabaya.

[6] Sidharta S.K. 1997. Irigasi dan Bangunan Air. Jakarta : Guna Darma.

[7] Soemarto, CD. 1987. Hidrologi Teknik. Jakarta : Penerbit Usaha Nasional.

[8] Soedasono, Suyono. 1985. Hidrologi Untuk Pengairan edisi 5. Jakarta : PT. Pradnya Paramita. 
Halaman ini sengaja dikosongkan

Hal 58 